\title{
Genetic and nongenetic variation in concentration of selenium, calcium, potassium, zinc, magnesium, and phosphorus in milk of Dutch Holstein-Friesian cows
}

\author{
K. J. E. van Hulzen, ${ }^{*}$ R. C. Sprong, $†$ R. van der Meer, $†$ and J. A. M. van Arendonk ${ }^{* 1}$ \\ ${ }^{*}$ Animal Breeding and Genomics Centre, Wageningen University, PO Box 338, $6700 \mathrm{AH}$ Wageningen, the Netherlands \\ †NIZO Food Research, PO Box 20,6710 BA Ede, the Netherlands
}

\begin{abstract}
Minerals found in milk, such as Se, Ca, K, Zn, $\mathrm{Mg}$, and $\mathrm{P}$, contribute to several vital physiological processes. The aim of this study was to quantify the genetic variation in levels of $\mathrm{Se}, \mathrm{Ca}, \mathrm{K}, \mathrm{Zn}, \mathrm{Mg}$, and $\mathrm{P}$ in milk and to quantify the between-herd variation in the levels of these minerals in milk. One morning milk sample from each of 1,860 Dutch Holstein-Friesian cows from 388 commercial herds in the Netherlands was used. Concentration of minerals was determined by inductively coupled plasma-atomic emission spectrometry. Variance components were estimated using an animal model with covariates for days in milk and age at first calving; fixed effects for season of calving and effect of test or proven bull; and random effects for animal, herd, and error. Heritability and proportion of phenotypic variation that can be explained by herd were estimated using univariate analysis. The intraherd heritability for Se was low (0.20) whereas herd explained $65 \%$ of the total variation in Se. Variation between herds most likely results from variation in Se content in the feed, which partly reflects variation in Se levels in the soil. Intraherd heritabilities for $\mathrm{Ca}, \mathrm{K}, \mathrm{Zn}$, $\mathrm{Mg}$, and $\mathrm{P}$ were moderate to high and were $0.57,0.46$, 0.41, 0.60, and 0.62, respectively. For Ca, K, Zn, Mg, and $\mathrm{P}$, the proportions of phenotypic variation that could be explained by herd were low $(0.13-0.24)$. This study shows that there are possibilities for altering the mineral composition of milk. For $\mathrm{Ca}, \mathrm{K}, \mathrm{Zn}, \mathrm{Mg}$, and $\mathrm{P}$, there are good prospects for selective breeding whereas, for Se, measures at farm level may be more effective.
\end{abstract}

Key words: milk mineral, heritability, nongenetic variation, dairy cow

Received May 20, 2009.

Accepted August 10, 2009.

${ }^{1}$ Corresponding author: johan.vanarendonk@wur.nl

\section{INTRODUCTION}

Human mineral intake worldwide varies widely, which results in different countries facing different health challenges. In several cultures, dairy products are an important source of minerals in the human diet (Jelen and Lutz, 1998). Minerals found in milk, such as Se, Ca, K, Zn, Mg, and P, contribute to several vital physiological processes. For example, Ca and P play an important role in bone metabolism, Se and $\mathrm{Zn}$ in immune responses, and $\mathrm{Ca}, \mathrm{K}$, and $\mathrm{Mg}$ in the regulation of blood pressure (Cashman, 2006; Haug et al., 2007).

Minerals represent a small fraction of milk solids compared with milk fatty acids and milk protein, but play an important role in the structure and stability of casein micelles. Caseins are important for cheese yield, milk coagulation time, and curd firmness (Wedholm et al., 2006). In addition, Ca appears to play a crucial role in cheese production. Insight into variation in mineral content of milk is, therefore, important for understanding the product properties of milk (Lucey and Fox, 1993).

Numerous studies have investigated nongenetic sources of variation in the mineral content of milk and have shown that mineral content is influenced by stage of lactation, nutritional status, and climate (Gaucheron, 2005; Cashman, 2006; Phipps et al., 2008). Information on genetic variation between cows as a factor in mineral content of milk is limited. Renner and Kosmack (1974) reported genetic variation in milk Ca content, which is related to high heritability of casein content. Davis et al. (2001) found a difference in milk Ca content between Jersey and Friesian cows. Furthermore, they found that cows with high or low Ca content maintained these characteristics within and across seasons. Their results are suggestive of a genetic basis to variation in milk $\mathrm{Ca}$ content. Recently, Soyeurt et al. (2008) found differences in $\mathrm{Ca}$ and $\mathrm{P}$ concentration measured using emission spectrometry in milk from different breeds. The existence of genetic variation in milk mineral content would offer the opportunity for novel breeding strategies that aim at producing milk with added value, such 
as increased levels of desired minerals, and the opportunity to determine the consequences of current breeding strategies for mineral content of milk.

The objective of this study was to quantify the genetic variation in levels of $\mathrm{Se}, \mathrm{Ca}, \mathrm{K}, \mathrm{Zn}, \mathrm{Mg}$, and $\mathrm{P}$ in milk and to quantify the between-herd variation in the level of these minerals in milk.

\section{MATERIALS AND METHODS}

\section{Animals}

This study is part of the Dutch Milk Genomics Initiative (Wageningen University, Wageningen, the Netherlands), a project that focuses on the genetic background of detailed milk composition. As part of this study, milk samples were collected from 1,953 first-parity cows in 398 commercial herds in the Netherlands. At least 5 cows per herd were present at the start of the experiment. Data collection was designed for estimating genetic parameters (many small families) and linkage analysis (some large families). We aimed to include 20 offspring from 50 young bulls and 200 offspring from 5 proven bulls; we included 857 offspring from 50 young bulls and 909 offspring from 5 proven bulls. To obtain the minimum of 5 offspring per herd, we included 187 offspring from other proven bulls. Each cow was between 5 and 220 DIM at the start of the experiment, and each cow carried at least $87.5 \%$ Holstein-Friesian genes. Pedigrees and milk yield records of each of the 1,953 selected cows were provided by the cattle cooperative (CRV, Arnhem, the Netherlands).

\section{Milk Samples}

Morning milk samples (1 milk sample per cow) from 1,948 Dutch Friesian cows in their first lactation, located in 398 herds, were collected. The samples were preserved with $0.03 \%$ (wt/wt) sodium azide, transported refrigerated, and stored frozen at $-40^{\circ} \mathrm{C}$ within 1 d. Cows were milked twice daily, but only the morning milk samples were analyzed for their concentrations of Se, Ca, K, Zn, Mg, and P. After data editing, information on 1,860 milk samples remained; all were used in the analysis.

\section{Determining Mineral Concentrations}

Milk mineral concentrations were determined by inductively coupled plasma-atomic emission spectrometry (ICP-AES; Vista Axial, Varian, Australia), which has the capability for simultaneous multi-element determination over a wide range, by using a modification of the method published by Asfaw and Wibetoe (2005).
Briefly, $2.5 \mathrm{~g}$ of milk was accurately weighed into Teflon vessels and mixed with $6 \mathrm{~mL}$ of $\mathrm{HNO}_{3}$ (70\%, Suprapur grade quality, Merck, Darmstadt, Germany). The mixture was digested using microwave-assisted destruction (MarshXpress, Beun de Ronde, Abcoude, the Netherlands) as follows. Sealed samples were heated linearly to $200^{\circ} \mathrm{C}$ for $20 \mathrm{~min}$, kept at $200^{\circ} \mathrm{C}$ for $35 \mathrm{~min}$, and then cooled to $50^{\circ} \mathrm{C}$. Subsequently, concentrated $\mathrm{HCl}$ was added to the mixture and the mixture was heated at $130^{\circ} \mathrm{C}$ for $10 \mathrm{~min}$, followed by cooling to room temperature. Finally, the mixture was supplemented with urea $(50 \% \mathrm{wt} / \mathrm{vol})$ to minimize nitrous gases and filled up with MilliQ water (Millipore, Amsterdam, the Netherlands) to bring the volume to $25 \mathrm{~g}$. Samples were diluted in MilliQ with cesium chloride (final volume 1\%) and directly introduced into the ICP-AES for measurement of Ca, K, Zn, Mg, and P. For Se measurement, samples were first converted to the hydride form using a VGA hydride system (VGA-77, Varian, Mulgrave, Australia) containing sodium boron hydride and $\mathrm{HCl}$ and were subsequently introduced into ICP. Inductively coupled plasma standards were determined every 20 measurements. When the coefficient of variance of the standard exceeded $10 \%$, samples were analyzed again. MilliQ water was subjected to the whole procedure to obtain blank measurements. If relevant, data were corrected for reagent blank.

To determine the coefficient of variation for the detection method, a reference milk sample was subjected to the whole procedure at every destruction cycle. In total, 105 reference samples were obtained for Se and 101 for non-Se samples. For Se, Ca, K, Zn, Mg, and P, the coefficients of variation for the reference samples were $14.3,7.9,9.3,11.7,6.2$, and 5.7, respectively. When the concentrations of reference samples were plotted against the mean concentration of the samples of the corresponding destruction round, statistically significant $(P<0.05)$ positive correlations were observed for all minerals. Correlation coefficients were 0.63 for Se, 0.73 for $\mathrm{Ca}, 0.95$ for $\mathrm{K}, 0.72$ for $\mathrm{Zn}, 0.84$ for $\mathrm{Mg}$, and 0.80 for P. Therefore, it was decided to correct the samples for the between-destruction round variation according to the following formula:

$$
y_{\text {corr }}=\frac{r e f_{\text {mean }}}{r e f} \times y
$$

where $y_{\text {corr }}=$ the corrected mineral concentration of the milk sample, $r e f_{\text {mean }}=$ the mean mineral concentration of all reference samples, $r e f=$ the mineral concentration of the reference sample of the corresponding destruction run, and $y=$ the mineral concentration of the milk sample. 
Table 1. Mean and CV for concentrations of selected minerals in milk samples from 1,860 primiparous Holstein-Friesian cows

\begin{tabular}{lrr}
\hline Mineral & Mean & CV \\
\hline $\mathrm{Se}(\mu \mathrm{g} / \mathrm{kg})$ & 22.75 & 26.4 \\
$\mathrm{Ca}(\mathrm{mg} / \mathrm{kg})$ & $1,235.38$ & 9.2 \\
$\mathrm{~K}(\mathrm{mg} / \mathrm{kg})$ & $1,612.36$ & 9.0 \\
$\mathrm{Zn}(\mu \mathrm{g} / \mathrm{kg})$ & $3,711.51$ & 18.2 \\
$\mathrm{Mg}(\mathrm{mg} / \mathrm{kg})$ & 115.87 & 10.1 \\
$\mathrm{P}(\mathrm{mg} / \mathrm{kg})$ & $1,027.56$ & 9.1 \\
\hline
\end{tabular}

\section{Statistical Analysis}

Variance components for genetic and herd effects were estimated with an animal model using ASReml (Gilmour et al., 2002). The animal model was the same as the one used in the other studies on detailed milk composition on the same data set (Stoop et al., 2006, 2008; Schopen et al., 2009):

$$
\begin{gathered}
y_{i j k l m n}=\mu+b_{1} \times \operatorname{dim}_{i}+b_{2} \times e^{-0.05 \times d i m}+b_{3} \times a f c_{j} \\
+b_{4} \times a f c_{j}^{2}+\text { season }_{k}+\text { scode }_{l}+\text { herd }_{m}+A_{n}+E_{i j k l m n},
\end{gathered}
$$

where $y_{i j k l m n}=$ dependent variable corresponding to milk mineral concentration of cow $n$ with a sire code of $l$, age of first calving $j$ during season $k$ and at DIM $i$; $\mu=$ general mean; $\operatorname{dim}_{i}=$ DIM (time between calving and date of sample), modeled with a Wilmink curve (Wilmink, 1987) with parameters $b_{1}$ and $b_{2} ; a f c_{j}=$ covariate describing the effect of age at first calving; $b_{3}$ and $b_{4}=$ regression coefficients for $a f c$ and $a f c^{2}$; season $k$ $=3$ classes for season of calving: summer (June-August 2004), autumn (September-November 2004), and winter (December 2004-February 2005); scode $_{l}=$ fixed effect accounting for differences between groups of proven bull daughters and young bull daughters; herd $_{m}=$ random effect of herd $m ; A_{n}=$ random additive genetic effect of animal $n$; and $E_{i j k l m n}=$ random residual effect. Univariate analyses were used to estimate the intraherd heritability $\left(h^{2}\right)$, which was defined as

$$
h^{2}=\frac{\sigma_{A}^{2}}{\sigma_{A}^{2}+\sigma_{E}^{2}},
$$

where $\sigma_{A}^{2}$ represents the additive genetic variance and $\sigma_{E}^{2}$ the residual variance. The intraherd heritability expresses the proportion of phenotypic variance that can be explained by additive genetic differences between animals within herds. The proportion of the total variance caused by herd $\left(h_{\text {herd }}\right)$ was calculated as:

$$
h_{\text {herd }}=\frac{\sigma_{\text {herd }}^{2}}{\sigma_{\text {herd }}^{2}+\sigma_{A}^{2}+\sigma_{E}^{2}},
$$

where $\sigma_{\text {herd }}^{2}$ is the between-herd variance.

\section{RESULTS}

\section{Mean and Coefficient of Variation}

Means and coefficients of variation for Se, Ca, K, Zn, $\mathrm{Mg}$, and $\mathrm{P}$ are in Table 1 . The mean levels of minerals ranged from $23 \mu \mathrm{g} / \mathrm{kg}$ for Se to $1,612 \mathrm{mg} / \mathrm{kg}$ for K. The coefficient of variation was largest for Se (26.4\%) and $\mathrm{Zn}(18.2 \%)$. The coefficients of variation of the other minerals were all close to $9 \%$.

\section{Intraherd Heritability}

Genetic parameters for the minerals are displayed in Table 2. The intraherd heritability $\left(h^{2}\right)$ ranged from 0.20 for Se to 0.62 for P. Based on the heritability estimates, the selected minerals could be divided into 3 groups. The intraherd heritabilities were low for Se, moderate for $\mathrm{K}$ and $\mathrm{Zn}$, and high for $\mathrm{Ca}, \mathrm{Mg}$, and $\mathrm{P}$.

\section{Effect of Herd and Lactation Stage}

Table 2 also provides estimates of the proportion of phenotypic variance that can be explained by variation in herd effects. For Se, variation in herd effects explained $65 \%$ of the phenotypic variance. For $\mathrm{Ca}, \mathrm{Zn}$, $\mathrm{Mg}$, and $\mathrm{P}$, variation in herd effects explained less than $16 \%$ of the phenotypic variance. For K, variation in herd effects explained $24 \%$ of the phenotypic variance.

The ratio of genetic:herd variance was calculated to quantify the relative importance of variation in genetic and herd effects. This ratio was larger than 3 for $\mathrm{Ca}$, $\mathrm{Mg}$, and $\mathrm{P}$, which shows that, for these minerals, variation in genetic effects is much larger than variation in herd effects. For Se, however, the ratio was only 0.13, which reveals that, for Se, variance between herds was much larger than genetic variance.

Stage of lactation had significant effect $(P<0.05)$ on all milk mineral concentrations, except for $\mathrm{P}$, although $\mathrm{P}$ decreased slightly with advancing lactation (Table 3). Levels of Ca, Zn, Mg, and Se increased during lactation whereas concentration of $\mathrm{K}$ in milk was found to decrease with stage of lactation. Forar et al. (1982) found that content of $\mathrm{P}$ was lower at the end of the lactation. The reason for the discrepancy with our results is not clear. 
Table 2. Additive genetic variance $\left(\sigma_{A}^{2}\right)$, herd variance $\left(\sigma_{h e r d}^{2}\right)$, residual variance $\left(\sigma_{E}^{2}\right)$, ratio of additive genetic variance over herd variance (ratio), intraherd heritability $\left(h^{2}\right)$, and herd variance as proportion of total variance $\left(h_{\text {herd }}\right)$ for $\mathrm{Se}, \mathrm{Ca}, \mathrm{K}, \mathrm{Zn}, \mathrm{Mg}$, and $\mathrm{P}$ as estimated from milk samples from 1,860 primiparous HolsteinFriesian cows (SE of estimates in parentheses) ${ }^{1}$

\begin{tabular}{lrrrrrr}
\hline Mineral & \multicolumn{1}{c}{$\sigma_{A}^{2}$} & \multicolumn{1}{c}{$\sigma_{\text {herd }}^{2}$} & \multicolumn{1}{c}{$\sigma_{E}^{2}$} & Ratio $^{2}$ & \multicolumn{1}{c}{$h^{2}$} & $h_{\text {herd }}$ \\
\hline $\mathrm{Se}$ & 2.54 & 23.57 & 10.39 & 0.11 & $0.20(0.08)$ & $0.65(0.02)$ \\
$\mathrm{Ca}$ & $6,504.48$ & $1,792.91$ & $4,951.65$ & 3.63 & $0.57(0.11)$ & $0.14(0.02)$ \\
$\mathrm{K}$ & $7,772.59$ & $5,301.44$ & $8,979.37$ & 1.47 & $0.46(0.10)$ & $0.24(0.02)$ \\
$\mathrm{Zn}$ & $155,885.00$ & $73,725.00$ & $228,337.00$ & 2.11 & $0.41(0.10)$ & $0.16(0.02)$ \\
$\mathrm{Mg}$ & 68.62 & 16.95 & 45.21 & 4.05 & $0.60(0.11)$ & $0.13(0.02)$ \\
$\mathrm{P}$ & $4,861.86$ & $1,420.67$ & $2,928.99$ & 3.42 & $0.62(0.10)$ & $0.15(0.02)$ \\
\hline
\end{tabular}

${ }^{1} \sigma_{P}^{2}=\sigma_{A}^{2}+\sigma_{E}^{2} ; h^{2}=\left[\sigma_{A}^{2} /\left(\sigma_{A}^{2}+\sigma_{E}^{2}\right)\right] ; \quad h_{\text {herd }}=\sigma_{\text {herd }}^{2} /\left(\sigma_{\text {herd }}^{2}+\sigma_{A}^{2}+\sigma_{E}^{2}\right)$.

${ }^{2}$ Ratio $=\sigma_{A}^{2} / \sigma_{\text {herd }}^{2}=$ ratio between additive genetic variance $\left(\sigma_{A}^{2}\right)$ and herd variance $\left(\sigma_{\text {herd }}^{2}\right)$.

\section{DISCUSSION}

This study estimated genetic and herd variance in concentrations of Se, Ca, K, Zn, Mg, and $\mathrm{P}$ in the milk of Dutch Holstein-Friesian cows. This knowledge is important for the evaluation of genetic and nongenetic strategies for changing the mineral composition of milk.

Although milk mineral composition is thought to be relatively constant (Gaucheron, 2005), our study revealed substantial variation in concentrations of $\mathrm{Se}, \mathrm{Ca}$, $\mathrm{K}, \mathrm{Zn}, \mathrm{Mg}$, and $\mathrm{P}$ in milk. The coefficient of variation of mineral concentration ranged from 9 to $26 \%$ (Table 1 ). In comparison, the coefficient of variation of lactation milk yield lies around 20\% (Stoop et al., 2008). Mineral content was determined in milk collected during a short sampling period in first-lactation cows that were all kept indoors. The coefficient of variation is likely to increase when samples are analyzed over a longer period of time by also including the summer season, during which many cows are kept outdoors.

Mean mineral concentrations of $\mathrm{Ca}, \mathrm{K}, \mathrm{Zn}, \mathrm{Mg}$, and $\mathrm{P}$ in milk in this study were comparable with concentrations found in other recent studies (Gaucheron, 2005; Haug et al., 2007). Mean concentration value of Se found in this study was $22.75 \mu \mathrm{g} / \mathrm{kg}$, which was in the range of values reported. Mean Se values generally varied between 6.1 and $24.3 \mu \mathrm{g} / \mathrm{L}$ with exception of seleniferous regions in, for example, the United States, where values of 64 and $74 \mu \mathrm{g} / \mathrm{L}$ were measured (Rodríguez Rodríguez et al., 2001).

For $\mathrm{Ca}, \mathrm{K}, \mathrm{Mg}$, and $\mathrm{P}$, the coefficients of variation ranged from 9.0 to $10.1 \%$. For Se and $\mathrm{Zn}$, the coefficients of variation were much higher (26.4 and $18.2 \%$, respectively), but these differences may be caused by mean values for Se and $\mathrm{Zn}$ being small $(\mu \mathrm{g} / \mathrm{kg}$ compared with $\mathrm{mg} / \mathrm{kg}$ for the other minerals). The larger coefficients of variation for these minerals could also reflect a larger measurement error.

To better identify sources of variation, we estimated the intraherd heritability, the proportion of phenotypic variance due to herds, and the ratio of genetic:herd variance (Table 2). The intraherd heritability for Se was low $(20 \%)$ whereas the herd variance in Se explained $65 \%$ of the total variance. The herd variance may result from differences between herds in housing, management, or feeding. Large effects of dietary Se content on Se content in milk have been reported in the literature (Haug et al., 2007; Muñiz-Naveiro et al., 2005; Phipps et al., 2008). A linear relation between the Se content of feed and the concentration of Se in milk has been reported by Van Dael et al. (1991). The concentration of Se in plants is influenced by the Se content and characteristics of the soil (Muñiz-Naveiro et al., 2005). The Se content of soil, known to vary widely between regions, influences the Se content in plants, which are used as roughages. Furthermore, it is known that Se content in milk can be increased by increasing Se content in the fertilizer that is applied to grassland. These findings suggest that a large part of the herd variance observed in this study was caused by

Table 3. Estimate of linear regression coefficient of DIM on concentration of $\mathrm{Se}, \mathrm{Ca}, \mathrm{K}, \mathrm{Zn}, \mathrm{Mg}$, and $\mathrm{P}$ as estimated from milk samples from 1,860 primiparous Holstein-Friesian cows ${ }^{1}$

\begin{tabular}{lrc}
\hline Mineral & Effect & SE \\
\hline $\mathrm{Se}(\mu \mathrm{g} / \mathrm{kg})$ & 0.011 & 0.005 \\
$\mathrm{Ca}(\mathrm{mg} / \mathrm{kg})$ & 0.578 & 0.136 \\
$\mathrm{~K}(\mathrm{mg} / \mathrm{kg})$ & -0.485 & 0.174 \\
$\mathrm{Zn}(\mu \mathrm{g} / \mathrm{kg})$ & 2.210 & 0.816 \\
$\mathrm{Mg}(\mathrm{mg} / \mathrm{kg})$ & 0.068 & 0.013 \\
$\mathrm{P}(\mathrm{mg} / \mathrm{kg})$ & -0.058 & 0.005 \\
\hline
\end{tabular}

${ }^{1}$ All coefficients were significantly $(P<0.05)$ different from zero except for P. 
differences in feed. Our study supports other studies stating that nongenetic factors and, most likely, feeding, are important for the concentration of Se in milk.

For the concentration of $\mathrm{Zn}$ in milk, we found a high intraherd heritability and a low herd variance. The herd variance of $\mathrm{Zn}$ in milk was surprisingly low given that several studies described large effects of feeding on Zn level (Salih et al., 1987). Wiking et al. (2008) showed that Zn concentration in bovine milk is significantly affected by the dietary intake of fat. Transfer of fat from diet to milk facilitates transfer of Zn from diet to milk. Today's cow diets contain low amounts of fat, which could explain the low herd variance found in our study. We hypothesize that because of the current use of low-fat diets, the herd variance of $\mathrm{Zn}$ content in milk has decreased. In the current study only winter samples were used; the variation in dietary fat resulting in variation in $\mathrm{Zn}$ concentration in milk may be larger in summer because of larger variation in dietary fat between herds in summer (Heck et al. 2009).

The herd variance in $\mathrm{K}$ appeared to be higher than the herd variance in $\mathrm{Ca}, \mathrm{Zn}, \mathrm{Mg}$, or $\mathrm{P}$. We hypothesized that variation in subclinical mastitis could be the cause. Mastitis causes changes in the conductivity of milk by damaging the mammary epithelium and thus altering the balance of $\mathrm{K}, \mathrm{Na}$, and $\mathrm{Cl}$ ions. In this research, a minimum of 3 animals per herd was used for analysis of the herd effect and, therefore, one animal having problems with mastitis could have a significant effect on the mean concentration level of $\mathrm{K}$ of that herd.

The intraherd heritabilities of $\mathrm{Ca}, \mathrm{Mg}$, and $\mathrm{P}$ were high and very similar $(0.57,0.60$, and 0.62 , respectively). The intraherd heritabilities of $\mathrm{K}$ and $\mathrm{Zn}$ were 0.46 and 0.41 , respectively. The origin of the genetic variance between cows in concentrations of $\mathrm{Ca}, \mathrm{Zn}, \mathrm{Mg}$, and $\mathrm{P}$ in milk is not clear. The nature of $\mathrm{Ca}, \mathrm{Zn}, \mathrm{Mg}$, and $\mathrm{P}$ secretion in milk is not fully understood, with $\mathrm{Ca}$ and $\mathrm{P}$ being the best studied. $\mathrm{P}$ in milk exists in several forms (e.g., phospholipids, colloidal Ca phosphate, and casein phosphoserines), all of which are known to show considerable genetic variation (Heck et al., 2008). Thus, part of the genetic variation in milk phosphorus can be explained by its casein phosphoserine residues. Milk Mg exists mainly as citrate, phosphate, and free ions. Only $35 \%$ of $\mathrm{Mg}$ is bound to casein micelles (Gaucheron, 2005); therefore, the number of casein phosphoserines might not be so important in determining the $\mathrm{Mg}$ variation in milk. The secretion of $\mathrm{Ca}$ in milk is a very complex phenomenon with a wide variety of forms, including casein-bound $\mathrm{Ca}$, colloidal Ca phosphate, Ca citrate, and free ionized Ca (Neville et al., 1995). The majority of $\mathrm{Ca}$ (about 65\%) is associated with casein micelles (Neville et al., 1995). Therefore, the number of casein phosphoserines in milk may determine Ca concentra- tions and maybe also $\mathrm{Zn}$ concentrations because the majority of $\mathrm{Zn}$ is also bound to casein micelles (Neville et al., 1995). However, this needs to be established. As Schopen et al. (2009) found, the intraherd heritability of casein content in milk was high (0.41). This heritability is similar to that for $\mathrm{Zn}$, which supports the link between Zn and casein. Alternatively, plasma membrane Ca ATPase isoform 2 (PMCA2) is involved in the secretion of $\mathrm{Ca}$ in milk; mutations of PMCA2 in mice result in lower milk Ca concentrations (Van Houten et al., 2007) and lowered the milk protein content (Reinhardt et al., 2004). Whether polymorphisms in the PMCA2 of the cow's mammary gland are responsible for the observed variation in milk $\mathrm{Ca}$ concentrations needs to be established.

The amount of change in a trait that can be realized by genetic selection is determined by the genetic variance in that trait. A dairy cattle breeding program that aims at a single trait can result in an annual genetic improvement of 0.04 to 0.06 genetic standard deviation (Meuwissen, 1998). Single trait selection on one mineral during a period of $10 \mathrm{yr}$ would lead to an improvement of between 3 and $5 \%$ of the content of that mineral. This shows the potential for genetic improvement but needs to be regarded as an upper estimate because selection of dairy cattle is based on multiple traits. For predicting the response to multiple trait selection, as well as the correlated response to the current selection program, information is needed on genetic correlations between traits considered in selection.

\section{CONCLUSIONS}

We observed differences between cows and herds in concentrations of minerals in milk and determined that concentrations in milk can be changed by way of nutrition or by genetic selection. The large coefficient of variation $(26 \%)$ for Se in combination with an intraherd heritability of 0.20 suggests that it is possible to alter Se content of milk by selection. However, $65 \%$ of the total variance can be explained by herd variance, indicating that changing Se levels in milk by nutrition is more effective. For concentration of $\mathrm{Ca}, \mathrm{K}, \mathrm{Zn}, \mathrm{Mg}$, and $\mathrm{P}$ in milk, selection is a more promising route for change.

\section{ACKNOWLEDGMENTS}

This study is part of the Milk Genomics Initiative and the project "Melk op maat," funded by Wageningen University (Wageningen, the Netherlands), the Dutch Dairy Association (NZO; Zoetermeer, the Netherlands), cattle cooperative CRV (Arnhem, the Netherlands), the Dutch Technology Foundation STW (Utrecht, the 
Netherlands), the Ministry of Economic Affairs (Den Haag, the Netherlands), and the provinces of Gelderland (Arnhem, the Netherlands) and Overijssel (Zwolle, the Netherlands). The authors thank the owners of the herds for their help in collecting the data; Rob Dekker, Arjan Schonewille, Roelie Holleman, Elly Lucas, and Suzanne van Steenis (NIZO Food Research, Ede, the Netherlands) for analyzing the milk samples; and CRV (Arnhem, the Netherlands) for supplying pedigrees and milk production data.

\section{REFERENCES}

Asfaw, A., and G. Wibetoe. 2005. Simultaneous determination of hydride (Se) and non-hydride-forming $(\mathrm{Ca}, \mathrm{Mg}, \mathrm{K}, \mathrm{P}, \mathrm{S}$ and $\mathrm{Zn}$ ) elements in various beverages (beer, coffee, and milk), with minimum sample preparation, by ICP-AES and use of a dual-mode sample-introduction system. Anal. Bioanal. Chem. 382:173-179.

Cashman, K. D. 2006. Milk minerals (including trace elements) and bone health. Int. Dairy J. 16:1389-1398.

Davis, S. R., V. C. Farr, S. O. Knowles, J. Lee, E. Kolver, and M. Auldist. 2001. Sources of variation in milk calcium content. Aust. J. Dairy Technol. 56:156.

Forar, F. L., R. L. Kincaid, R. L. Preston, and J. K. Hillers. 1982. Variation of inorganic phosphorus in blood plasma and milk of lactating cows. J. Dairy Sci. 65:760-763.

Gaucheron, F. 2005. The minerals of milk. Reprod. Nutr. Dev. 45:473-483.

Gilmour, A. R., B. J. Gogel, B. R. Cullis, S. J. Welham, and R. Thompson. 2002. ASReml User Guide. Release 1.0. VSN International Ltd., Hemel Hempstead, UK.

Haug, A., A. T. Høstmark, and O. M. Harstad. 2007. Bovine milk in human nutrition - A review. Lipids Health Dis. doi:10.1186/1476$511 \mathrm{X}-6-25$

Heck, J. M. L., N. J. Olieman, A. Schennink, H. J. F. van Valenberg, M. H. P. W. Visker, R. C. R. Meuldijk, and A. C. M. van Hooijdonk. 2008. Estimation of variation in concentration, phosphorylation and genetic polymorphism of milk proteins using capillary zone electrophoresis. Int. Dairy J. 18:548-555.

Heck, J. M. L., H. J. F. van Valenberg, J. Dijkstra, and A. C. M. van Hooijdonk. 2009. Seasonal variation in the Dutch bovine raw milk composition. J. Dairy Sci. 92:4745-4755.

Jelen, P., and S. Lutz. 1998. Functional milk and dairy products. Pages 357-380 in Functional Foods: Biochemical and Processing Aspects. Vol. 1. G. Mazza, J. Shi, and M. Le Maguer, ed. CRC Press, Boca Raton, FL.

Lucey, J. A., and P. F. Fox. 1993. Importance of calcium and phosphate in cheese manufacture: A review. J. Dairy Sci. 76:1714-1724.

Meuwissen, T. H. E. 1998. Optimizing pure line breeding strategies utilizing reproductive technologies. J. Dairy Sci. 81:47-54.

Muñiz-Naveiro, Ó., R. Domínguez-González, A. Bermejo-Barrera, J. Cocho de Juan, J. M. Fraga Bermúdez, A. Goris Pereiras, A. López Santamariña, I. Martínez Lede, J. Valledor Puente, L. FernándezCouto Gómez, and P. Bermejo-Barrera. 2005. Selenium content and distribution in cow's milk supplemented with two dietary selenium sources. J. Agric. Food Chem. 53:9817-9822.

Neville, M. C., P. Zhang, and J. C. Allen. 1995. Minerals, ions and trace elements in milk. Pages 577-592 in Handbook of Milk Composition. R. G. Jensen, ed. Academic Press Inc., San Diego, CA.

Phipps, R. H., A. S. Grandison, A. K. Jones, D. T. Juniper, E. Ramos-Moralos, and G. Bertin. 2008. Selenium supplementation of lactating dairy cows: Effects on milk production and total selenium content and speciation in blood, milk and cheese. Animal $2: 1610-1618$.

Reinhardt, T. A., J. D. Lippolis, G. E. Shull,, and R. L. Horst. 2004. Null mutation in the gene encoding plasma membrane Ca2+ATPase isoform 2 impairs calcium transport into milk. J. Biol. Chem. 279:42369-42373.

Renner, R., and U. Kosmack. 1974. Genetic aspects of the mineral content of milk. Pages 38-39 in Proc XIX International Dairy Congress. New Delhi, India.

Rodríguez Rodríguez, E. M., M. Sanz Alaejos, and C. Díaz Romero. 2001. Mineral concentrations in cow's milk from the Canary Island. J. Food Compos. Anal. 14:419-430.

Salih, Y., L. R. McDowell, J. F. Hentges, R. M. Mason Jr., and C. J. Wilcox. 1987. Mineral content of milk, colostrum, and serum as affected by physiological state and mineral supplementation. J. Dairy Sci. 70:608-612.

Schopen, G. C. B., J. M. L. Heck, H. Bovenhuis, M. H. P. W. Visker, H. J. F. van Valenberg, and J. A. M. van Arendonk. 2009. Genetic parameters for major milk proteins in Dutch Holstein-Friesians. J. Dairy Sci. 92:1182-1191.

Soyeurt, H., V. M.-R. Arnould, D. Bruwier, P. Dardenne, J.-M. Romnee, and N. Gengler. 2008. Relationship between lactoferrin, minerals, and somatic cells in bovine milk. J. Dairy Sci. 91(E-Suppl. 1):1542-1543. (Abstr.)

Stoop, W. M., H. Bovenhuis, and J. A. M. van Arendonk. 2006. Genetic parameters for milk urea nitrogen in relation to milk production traits. J. Dairy Sci. 90:1981-1986.

Stoop, W. M., J. A. M. van Arendonk, J. M. L. Heck, H. J. F. van Valenberg, and H. Bovenhuis. 2008. Genetic parameters for major milk fatty acids and milk production traits of Dutch HolsteinFriesians. J. Dairy Sci. 91:385-394.

Van Dael, P., G. Vlaemynck, R. Van Renterghem, and H. Deelstra. 1991. Selenium content of cow's milk and its distribution in protein fractions. Z. Lebensm. Unters. Forsch. 192:422-426.

VanHouten, J. N., M. C. Neville, and J. J. Wysolmerski. 2007. The calcium-sensing receptor regulates plasma membrane calcium adenosine triphosphatase isoform 2 activity in mammary epithelial cells: A mechanism for calcium-regulated transport into milk. Endocrinology 148:5943-5954.

Wedholm, A., L. B. Larsen, H. Lindmark-Månsson, A. H. Karlsson, and A. Andrén. 2006. Effect of protein composition on the cheesemaking properties of milk from individual dairy cows. J. Dairy Sci. 89:3296-3305.

Wiking, L., T. Larsen, and J. Sehested. 2008. Transfer of dietary zinc and fat to milk-evaluation of milk fat quality, milk fat precursors, and mastitis indicators. J. Dairy Sci. 91:1544-1551.

Wilmink, J. B. M. 1987. Adjustment of test-day milk, fat and protein yield for age, season and days-in-milk. Livest. Prod. Sci. 16:335348. 